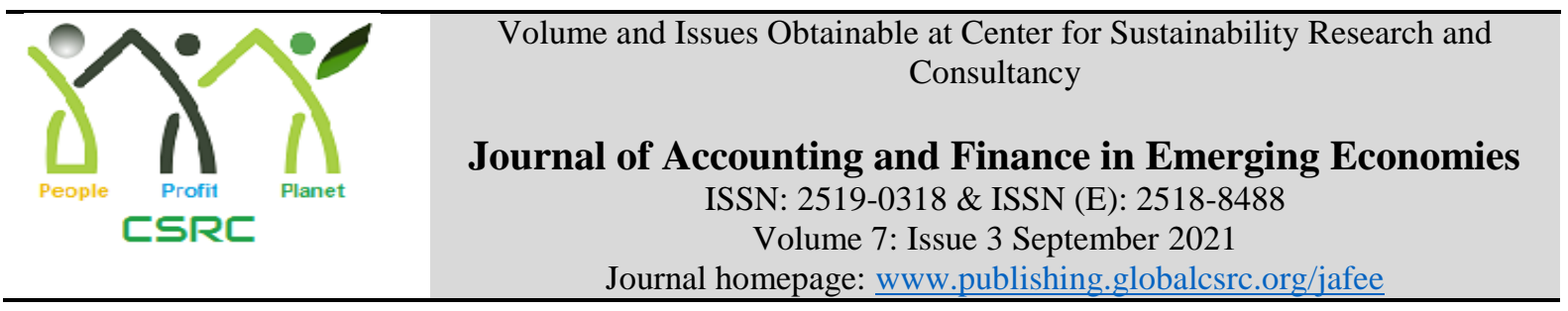

\title{
An Analysis of Sovereign Credit Ratings Impact on Financial Development in South Africa
}

Shanana Desiree' Motseta, MCom Investment Management- UJ; Senior analyst at Vodacom Pty Ltd, South Africa

*Oliver Takawira, Lecturer MDevF-USB, CDFA-CIDEF and MCSI-CISI, Department of Finance and Investment Management (DFIM), College of Business and Economics (CBE); University of Johannesburg, South Africa

*Corresponding author's email: otakawira@uj.ac.za

\begin{tabular}{l}
\hline ARTICLE DETAILS \\
\hline History \\
Revised format: Aug 2021 \\
Available Online: Sep 2021 \\
\hline Keywords \\
Sovereign Credit Ratings, \\
Financial Development, \\
ARDL, ECM and \\
Cointegration. \\
\hline JEL Classification \\
C01, C58, F65, G00, G24, \\
O16
\end{tabular}

\begin{abstract}
Purpose: The study analyses the effects of sovereign credit ratings on financial development in South Africa. This became important considering that the country has been receiving negative ratings of late.
\end{abstract}

Design/Methodology/Approach: Quarterly data for the period 1994-2017 was analysed using the Auto-Regressive Distributed Lag (ARDL) cointegration model and its associated statistics. The Error Correction Model (ECM) was implemented to augment the results of ARDL analysing the short run dynamics. The model was chosen given the order of integration of the variables. Financial development was selected since it influences financial conditions and financial sector stability.

Findings: The statistical results revealed that sovereign ratings positively influence financial variables that is in other words higher ratings are found to contribute positively to the growth of the financial development sector. Negative ratings are likely to affect the financial system as due to low access to external funding and exodus of investors, financial development is halted or decreased.

Implications/Originality/Value: The results suggest that authorities need to consider the factors which are targeted by rating agencies and ensure that they perform as expected. Governments should focus on raising sovereign ratings and avoiding downgrades to boost financial development.

\section{OPEN ACCESS}

(C) 2021, The authors, under a Creative Commons AttributionNonCommercial 4.0

Recommended citation: Motseta, S. D. Takawira, O. (2021). An Analysis of Sovereign Credit Ratings Impact on Financial Development in South Africa. Journal of Accounting and Finance in Emerging Economies, 7 (3), 553-571. 


\section{Introduction}

The role of finance on the development process is an area which has attracted academic attention even though conclusions vary. The literature available on the role of finance illustrates the importance of a-developed financial sector in the economic growth cycle, some of this literature includes Greenwood and Jovanovic (1990); Levine (1997); Levine and Zervos (1998); Rajan and Zingales (1998); Beck et al. (2000); Carlin and Mayer (2003); Claessens and Laeven (2003); Fisman and Love (2004); Ndikumana (2005). Suk-Joong and $\mathrm{Wu}$ (2007) highlight that a well-developed financial sector plays a crucial role in mobilising and allocating capital towards the profitable and generative sectors of the economy, which subsequently promotes economic growth.

Suk-Joong and $\mathrm{Wu}$ (2007) also highlight that there are a number of issues which have hampered the capabilities of the financial system in executing its role. These factors include unstable macroeconomic factors and transparency of the government concerning policies on attracting investors. This has caused the financial sector to fail in mobilising adequate financial resources for development, resulting in the country relying on international finance. There is also several empirical literature which have researched the determinants of financial sector development. These studies include Beck et al. (2000); Stulz and Williamson (2003); Chinn and Ito (2006). These studies indicate that the state of institutions in the domestic economy, state of the economy, political and legal domains do play a role in financial sector development.

Suk-Joong and $\mathrm{Wu}(2007)$ adds to this by stating that the impact of sovereign ratings on the domestic economy is another important factor which has not received sufficient attention when it comes to the analysis of the determinants of financial sector growth. The authors highlight that sovereign ratings influences developments within the domestic front as well as the potential of the country to obtain foreign capital. Suk-Joong and Wu (2007:14) further emphasize the extent to which sovereign credit or debt ratings have an influence on the domestic economy and is of importance because it shows "the relationships between the development of financial intermediation and a country's perceived willingness and ability to repay its debts, on which financial stability depends. This is important not only because international lenders often look to sovereigns to provide implicit payment guarantees to private borrowers and the sovereigns, financial positions in both local and foreign currencies play a crucial role in this regard. Also, private debt issuers' credit rating relies on the country's sovereign ratings".

Sovereign ratings simply indicate the government's ability and capacity to contractually repay its debt in a timely manner (Takawira \& Mwamba, 2020; and Canuto, Santos, Pabl, Pereira Dos \& Porto, 2012). The better the rating, the more likely a state can keep up with its debt repayments and vice versa. These ratings also provide an indicator of the degree of risk associated with investors' bond investments in the government. Sovereign ratings influence the fixed income markets for securities such as bonds (Takawira \& Mwamba, 2021; Charlin \& Cifuentes, 2015). At present, Fitch Ratings, Moody's and Standard \& Poor are the top credit rating agencies (CRA) that issue such ratings to different countries (Takawira \& Mwamba, 2020). It was only in 1975 that the Securities and Exchange Commissions recognized rating agencies on a national level (Berglund \& Fransson, 2012). Rating agencies have evolved since then, but their role for providing investors with information regarding the ability for an entity or state to repay debt still stands.

In 2017, South Africa was relegated to sub-investment grade (Takawira \& Mwamba, 2020). Consequently, the cost of debt for both corporations and the government increased as the probability of default risk also increased. 
This, according to Alexander Forbes would mean that South Africa will be removed from the Citi World Bond Index, which will see investors selling off an estimated US\$5 billion in bonds (Takawira, 2020). This poses a major threat to South Africa's financial system and stability. It also has a considerable impact on the ability of the country's financial system to mobilise finance, as investors will view the country as risk.

\section{Problem Statement}

Ntswane (2014) highlights that sovereign ratings are noted as one of the biggest pain points facing the South African economy. Given that the country's bonds are regarded as risky, this has reduced the appetite externally for South African bonds. However, these downgrades have happened during a time where the country was faced with numerous challenges. Firstly, South Africa has low and insufficient national savings. Abedian (2016) highlights that for the year 2016, the South African internal savings rate was estimated at $15 \%$ of GDP while investment needed to achieve 3\% growth per year for the country was around 30\% of GDP. This shows that the funds, which companies raise, and the state through the bond market plays a huge part in promoting domestic economic advancement.

Secondly, the domestic economy is plagued by various socio-economic problems such as high unemployment rates, high poverty rates and rising inequality (Abedian, 2016). These issues could be addressed if the economy had enough savings to aid in the growth of the economy as per the economic theory, which argues that growth is the solution to the triple evils mentioned above.

Lastly, given the downgrades, it means that it is now expensive to borrow externally (Takawira, 2020). The two options, which may be at the discretion of the government, will be to borrow from other governments or intergovernmental organisations, those include the International Monetary Fund and the World Bank. Abedian (2016) further highlights that such a move is criticised in that the country may lose its sovereignty.

This study focuses on analysing the effects of sovereign ratings on South Africa's financial sector development. The specific objective of the research is to econometrically test the relationship between sovereign ratings and financial sector development in South Africa. It aims to answer the question: Do sovereign credit ratings affect financial development?

Abedian (2016) highlighted that sovereign ratings have an essential function in mobilising financial resources, particularly in emerging economies. This paper will thus contribute to the existing literature through analysing how sovereign ratings affect financial development in South Africa.

\section{Literature Review}

\section{Theoretical Literature}

There are a number of theories that have been brought forth to clarify how sovereign credit ratings can have an impact on the development of the financial sector. Sovereign rates simply reflect the State's capacity and desire to service its maturing obligations. (Takawira \& Mwamba, 2020; Canuto, Santos, Pabl, Pereira Dos \& Porto, 2012). The better the rating, the more likely a state can keep up with its debt repayments and vice versa.

Rating agencies have evolved and have, over the years, found themselves under scrutiny for the information they provide together with how they derive this information (Takawira \& Mwamba, 2021). Needless to say, they still are depended upon by many market participants for information of different governments. CGFS (2011) report shows that sovereign ratings affect the banks' ability to raise finance. Higher sovereign risk pushed up costs for banks (Takawira \& Mwamba, 2021). 


\section{Channels Through which Sovereign Risk Affects Banking Sector}

The CGFS (2011) shows how sovereign risk affects the financial sector development, specifically the banking sector along with bank funding. This report shows that sovereign credit affects the financial system through government securities which are traded by financial intermediaries. There are four ways in which this is likely to be felt.

Firstly, "losses on holdings of government debt weakens banks' balance sheets, increasing their riskiness and making funding to be more costly and difficult to obtain" CGFS (2011:5). Secondly, greater sovereign volatility also decreases the value of funding banks that can be used to collect wholesale financing as well as the capital requirements of the central bank. Lastly, it is argued that when there is a downgrade, this also flows to the domestic commercial banks. This will increase the wholesale funding costs. This again will have serious effects on the ability of the bank to access the market. Finally, CGFS (2011) also shows that sovereign credit downgrades reduce the financing incentives which banks may gain from sovereign guarantees.

The CGFS (2011) shows that in addition to the four channels discussed above, there are eight additional channels through which sovereign credit rating may influence financial sector development through its effect on the banking sector. These channels are discussed in table I below.

Table I:

Channels Through which Sovereign Credit Rating may Influence Financial Sector Development

\begin{tabular}{|c|c|}
\hline The Transmission Channels & Explanation \\
\hline Asset Holding Channel & $\begin{array}{l}\text { The CGFS (2011) report shows that when a country's sovereign status is } \\
\text { revised down, that may affect the commercial banks by its possession of } \\
\text { government debt. Losses which are likely to be experienced will weaken the } \\
\text { banks' balance sheets. This will also increase their riskiness, which might } \\
\text { influence the cost and availability of funding. }\end{array}$ \\
\hline $\begin{array}{l}\text { The Collateral/Liquidity } \\
\text { Channel }\end{array}$ & $\begin{array}{l}\text { The CGFS (2011) report also indicates that banks typically use sovereign } \\
\text { securities as assurance to acquire central bank wholesale funding. These are } \\
\text { also used in securing funding in the private repo market, when issuing } \\
\text { covered bonds as well as when trading derivatives in the informal market } \\
\text { (over the counter). A sovereign credit rating downgrades reduce the } \\
\text { securities which can be used as collateral. This therefore reduces the banks' } \\
\text { funding capacity. }\end{array}$ \\
\hline $\begin{array}{l}\text { Sovereign ratings and bank } \\
\text { ratings }\end{array}$ & $\begin{array}{l}\text { CGFS (2011) shows also that sovereign credit ratings affect domestic banks } \\
\text { rating. A downgrade will usually be associated with a downgrade of the } \\
\text { domestic banks. Falzon }(2013: 4) \text { which shows that "sovereign ratings } \\
\text { generally represent a ceiling for the ratings of domestic banks". }\end{array}$ \\
\hline $\begin{array}{l}\text { Effect of government } \\
\text { guarantees on bank funding }\end{array}$ & $\begin{array}{l}\text { There are studies such as Alessandri and Haldane (2009), Panetta et al. } \\
\text { (2009) and Gropp et al. (2010) show that governments guarantee bank } \\
\text { funding. Alessandri and Haldane (2009) show that following the collapse of } \\
\text { the Lehman Brother, several developed countries provided support to their } \\
\text { banks. In the event of a worsening fiscal position, this could therefore have } \\
\text { huge effects on the government providing any guarantee. }\end{array}$ \\
\hline International spill overs & $\begin{array}{l}\text { The CGFS (2011) report shows that there are close links among financial } \\
\text { markets of developed countries. The CGFS (2011:25) argued that } \\
\text { "contagion may also be induced by banks' claims on non-bank private } \\
\text { entities in countries hit by sovereign tensions." }\end{array}$ \\
\hline Risk aversion channel & $\begin{array}{l}\text { The CGFS (2011) report shows that as investors become more risk averse, } \\
\text { they may demand a high premium on banks' securities. This will have a } \\
\text { huge effect on funds available for the bank as it becomes expensive to } \\
\text { borrow. This could also affect bank's profit as it may result in a decline in } \\
\text { asset prices. }\end{array}$ \\
\hline Impact on bank's non-interest & The CGFS (2011) report shows that a sovereign debt downgrade may affect \\
\hline
\end{tabular}




\begin{tabular}{|l|l|}
\hline income & $\begin{array}{l}\text { a banks' fee as well as trading income. A downgrade will significantly } \\
\text { influence the market value of investments which are managed by banks on } \\
\text { behalf of customers. This will squeeze the profits available to the bank. } \\
\text { Investors may also rebalance their portfolios to lower risk securities which is } \\
\text { likely to influence fees which the bank may collect and hence its } \\
\text { profitability. }\end{array}$ \\
\hline $\begin{array}{l}\text { Crowding-out effect on debt } \\
\text { issued by banks }\end{array}$ & $\begin{array}{l}\text { The CGFS (2011) shows also that a sovereign debt downgrade may also } \\
\text { result in crowding out of private debt which is issued as it increases the } \\
\text { costs. This may also be through a reduction in the funds available to banks. } \\
\text { This arises as the government will be borrowing in the domestic economy } \\
\text { given the challenges which comes with borrowing externally. }\end{array}$ \\
\hline
\end{tabular}

Source: Authors' Compilation

The discussion above shows that sovereign ratings affect the financial sector through its effect on the banking sector. Thus, sovereign ratings have far reaching consequences apart from affecting government borrowing only.

\section{Empirical Literature}

Kim and $\mathrm{Wu}$ (2008) examined the effect of credit ratings on financial development through capital flows. The authors focused on sovereign ratings by Standard and Poor's rating agency in the case of 51 emerging markets using panel data. The study found that sovereign ratings influence financial development. They further found that sovereign credit rating is a major component in attracting capital flows.

Rosenius and Sharafuddin (2013) examined the effect of Moody's sovereign credit rating of the stock markets from 2008 to 2012. The study made use of price series data taken from 11 European countries that have $80 \%$ GDP ratio and above. Using ordinary least squares (OLS), the study found that Moody's announcement changes have no impact on stock markets. Aman, Jain and Malik (2018) indicated that equity markets react due to capital outflows, and that sovereign credit rating information by rating agencies reduces asymmetric information thereafter both global and domestic investors will reallocate their capital.

Kim and $\mathrm{Wu}(2008)$ indicate that in assessing the extent to which sovereign ratings influences financial sector development, it is important to first understand the role of the financial system in the economy. It is argued that the financial sector as highlighted earlier plays a role of matching savers and borrowers. Kim and Wu (2008:6) also suggest that "the hallmarks of a developed financial system include an effective legal system that enforces the protection for property rights and financial contracting; transparent accounting and disclosure systems; a good reputation for sound policy making and macroeconomic management; and adequate regulatory infrastructure and institutional quality".

The authors further show that "a good reputation" for sound policymaking' is essential in supporting the whole financial system and enhancing its development. Kim and $\mathrm{Wu}$ (2008) further show that given that credit ratings encompass aspects of financial sector development, there are high chances that they will influence financial decisions. The authors also show that there are high chances that sovereign credit ratings have an influence on the role of the financial sector in mobilising and allocating financial resources to productive sectors of the economy.

Li, Pervaiz, Khan, Rehman and Olah (2019), shows that sovereign credit rating serves two main purposes. Firstly, it is argued that it verifies the financial conditions of a country. Secondly, credit ratings signal changes to the prevailing financial conditions in a country. 
There are several studies which have been carried out to examine how downgrades and upgrades influences the financing conditions within a country.

While on other hand Luitel and Vanpee (2018) lauded the importance of sovereign credit rating in improving financial development in emerging economies. They indicated that a sovereign rating influences the structure of bank assets. In the case of a positive rating, that leads to growth in bank assets. Regarding the government, it helps the government in being less reliant on bank financing and to encourage international bond markets. Therefore, a positive sovereign rating is likely to attracts foreign investment in the form of FDI and portfolio investments.

A study by Cooke and Bailey (2015) was carried out on the impact of sovereign credit rating and international bond price in the case of Jamaica between November 2008 and June 2015. The study mainly focused on sovereign credit rating by Moody's and S\&P. Using the event study technique, the study found that the market reacted to both downgrades and upgrades. With credit rating relative to Moody's, the study further indicated that the market is more responsive to $\mathrm{S} \& \mathrm{P}$ sovereign and investors are more sensitive to downgrades than upgrades.

There are several studies in South Africa which have been carried out to examine the effect of sovereign credit rating on the economy. These studies include Mugobo and Mutize (2018), Wortmann (2010), Ntsalaze and Boako (2016), Naeem (2012) and De Haan (2017) and Venkatraman (2015). These studies utilised different models and results are varied. However, the majority of these studies have largely focused on analysing the effect of sovereign credit rating on the country's capital inflows and outflows.

Starting with the work done by Mugobo and Mutize (2018), the authors examined how a sovereign rating downgrade affect foreign direct investment in South Africa between 2004 and 2014 utilising an event study. The empirical results revealed that the effect of the downgrades from the three major rating agencies in South Africa do not have the same effect on capital inflows into the country. The effect of a Moody's downgrade was found to be more pronounced as compared to what is experienced from other rating agencies.

However, this was found to be contrary to the finding of Wortmann (2010), who established that a sovereign rating by $\mathrm{S} \& \mathrm{P}$ affected foreign portfolio inflows into South Africa. This was found to be consistent with Bayar and Kalic (2014) who further showed that Moody's had a second large effect and lastly Fitch.

In another study, Ntsalaze and Boako (2016) studied the impact of sovereign credit ratings on legal entities in South Africa, with particular emphasis on the extent to which the sovereign credit rating reduces the amount of capital inflows into the country. The authors focused on credit allocation to legal entities operating in the domestic economy. The findings revealed that a negative rating limits the amount of capital which the firm could attract. These results were found to be consistent with Naeem (2012) and De Haan (2017). These authors argue that sovereign credit rating indeed influence private firms access to external credit.

Venkatraman (2015) employing an event study for 364 sovereign credit rating announcements for the period 1 January 2005 to 31 December 2013, also examined the extent to which the Johannesburg Securities Exchange share prices react to credit rating notices. The empirical results revealed that the JSE share prices are not responsive to new information related to sovereign credit rating announcements.

Ntswane (2014) conducted a study into the link between rating agencies long-term foreign sovereign ratings and the various forms of capital flows to Africa. The study utilised a 
comprehensive data set for 28 African countries for the period from 1994 to 2011 . The study utilised both a panel regression model and event study. The empirical results revealed that changes in sovereign ratings have an influence FDI, FPI and bank credit. The event studies result also demonstrated that rating announcements influence the stock market.

It was also found out that at empirical level the extent to which sovereign credit ratings affects financial variables differs according to the rating agents. There were contradictions on the relationship between sovereign ratings and stock market as some mentioned that sovereign rates do not affect stock markets.

\section{Research Methodology}

This section is carried out to provide an outline of the methodology that was used in ensuring that the objectives stated above were met. This analysis therefore thoroughly utilized the quantitative research framework to assess, measure and explain the impact of sovereign credit ratings on South African financial development.

This measure has enabled a constructive evaluation of the research topic and a cognitive development of the interest variables regarding South Africa. This research therefore gathered secondary data from organizations responsible for publishing relevant data.

The research used quarterly data for the time frame between 1994 to 2017 . This is the time span during which the South African economy had also gone through a series of rankings by the respective rating agencies. The data utilized in this analysis was derived from rating firms, the World Bank and the Reserve Bank of South Africa.

\section{Model specification}

The study follows the work of Kim and Wu (2008). The authors estimated two equations which were used to examine how sovereign credit ratings affect financial development.

The models were adopted and amended to incorporate variables, which are country specific. The models are estimated as follows:

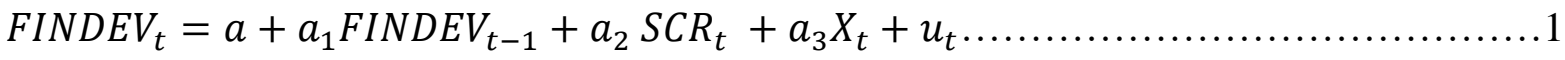
Where FINDEV measures financial sector development, SCR is Sovereign credit rating, $X$ captures several control variables which include GDP, internal investment which is represented by Gross Fixed capital Formation (GFCF), Inflation, and interest rate.

The sovereign credit ratings utilised in the study is by Standard and Poors (S\&P). The S\&P rating includes long-term ratings as well as their outlook for a period of six months. The long-term rating rank begins at AAA that represents the top credit quality, and goes down to the least quality represented by $\mathrm{D} / \mathrm{SD}$. In this case $\mathrm{D} / \mathrm{SD}$ stands for default/selective default. The rating BBB- are considered to be investment grade rating, whilst $\mathrm{BB}^{+}$are considered to be speculative. Kim and $\mathrm{Wu}$ (2008) show that short-term ratings can be anything from A-1 to $\mathrm{D} / \mathrm{SD}$. Also, the investment grade is A-3 and above. Also, the ratings are attached with rating outlooks which varies "Credit Watch-Positive" to "Credit Watch-Negative".

The study followed the work of Kim and $\mathrm{Wu}$ (2008) as well as Gande and Parsley (2005) where S\&P ratings were sequentially converted into time series data. As per Kim and Wu (2008) and Gande and Parsley (2005), numerical values were assigned for every grade ranking, scaling from 0 for default to 20 for AAA for the ratings that span over the long term. The long-term ratings have also been modified to integrate the outlook for each ranking. For example, where a rating specific to a period is AA (18), with a corresponding positive outlook of (0.25), the total long-term rating was captured as 18.25. 
As a proxy for the financial development, this study utilised domestic credit to the private sector (DCP). This is consistent with Kim and Wu (2008), Beck, Demirguc-Kunt and Levine (2000) and Kapingura and Alagidede (2016). Kapingura and Alagidede (2016) indicate that there are different views regarding the function of the financial sector development within the economy.

The first view suggests that financial development improves resource mobilisation, resulting in enhanced savings. This view is also supported by Sahoo and Dash (2013). This will therefore result in improved financial conditions. The second line of thought highlights that financial development has the capacity to make access to finance easy. This is likely to boost consumption (Nair, 2006).

According to this view, financial sector development may not really result in enhanced savings, therefore it might not improve the financial conditions within the country. Given the two different views, in line with Ang (2008) and Adenutsi (2010), for this paper, a positive relationship is expected between sovereign ratings and financial development. In other words a higher rating is expected to result in financial development in the domestic economy.

This is also supported by Kim and Wu (2008). These authors argue that the government plays a very important role in the early stages of financial market development. The authors also show that the "government can also play a very important role of providing financial and non-financial safety nets to companies that are considered to be of some national significance. As such, government's fiscal position would then be seen as one of the indicators of financial market development potential." (Kim \& Wu, 2008:12). It also assumes that financial development promotes investment instead of consumption.

With regards to the control variables, their relationship with the dependent variable depends on what is measured at a time. GDP, GFCF and interest rates are expected to have a positive relationship with financial sector development. Higher rates of growth and investment are likely to result in higher demand for financial resources, which in turn results in improved financial sector development, as it tries to match the demand of resources.

At the same time, higher interest rates may result in higher savings, as investors try to take advantage of the higher returns. Also, inflation is expected to influence financial sector development positively. Higher inflation rates may force people to prefer investing on the stock market as compared to keeping and saving cash. This therefore results in more funds flowing into the stock market.

\section{Estimation Techniques}

As pointed out by Brooks (2008), the data was all tested for stationarity so as to determine the time series properties of the data. This is very important as it determines the techniques, which should be used in the study. Apart from informal checks which involve graphical analysis, formal tests were also carried out so as to determine the order of integration of the data. The formal tests carried out are the Augmented Dickey Fuller model (ADF) and Phillips Peron (PP) tests.

\section{Cointegration Tests}

Given that the variables of interest were found to be integrated of different orders, that is level series and first difference, appropriate cointegration tests were therefore conducted.

After establishing the level at which the data is stationary, the second step focused on finding the lag length which is appropriate. There are various avenues to deal with the problem of lag length selection. Khim-SenLiew (2004) shows that the standard approach is to rely on the 
different information criterions. The author shows that these information criterions include "Aikaike's information criterion (AIC), Schwarz information criterion (SIC) and HannanQuinn criterion (HQC)". With regard to these criteria, Khim-SenLiew (2004) shows that the AIC has been traditionally endorsed in economic studies.

Having chosen the correct lag length, the next step was to choose the appropriate method of cointegration. There are different approaches to cointegration. These include the Engle Granger (EG) two step approach, the Johansen approach and the Auto-Regressive Distributed Lag (ARDL) model. The EG model has been criticised in that it requires one to specify a variable as endogenous and another as an exogenous variable. However, the Johansen test to cointegration takes this problem into account as it is a multivariate model. It is also important to consider that all the tests can be employed provided that the data is integrated of order 1 . However, in the event that the data is integrated of different order, the ARDL model becomes the best technique.

In the event that the data to be used in analysis is integrated of order 1 , that is $I(1)$, then all the methods are compatible. However, in the event that the date is mixed, the ARDL model becomes more superior. The data utilized in the study was found to be integrated of different orders. Therefore, the ARDL model to cointegration was chosen in analysing the variables of interest.

The ARDL approach is more efficient on the long run parameter estimates and is often more heterogeneous, given that it enables the estimated standard errors to be unbiased. More of the ARDL parameters can be freely estimated and the error correction coefficient requires restriction far less frequently than is the case with the Engle Granger approach. According to Pesaran and Pesaran (1997) the ARDL also has advantages over other approaches because it fixes the endogenous regressors and autocorrelation problem at once.

It is believed that the approach is flexible because it can be employed even if the variables are of different order, while other approaches, like Johansen approach, requires the variables to be of the same order (Pesaran \& Pesaran, 1997).

ARDL estimates and t-tests sizes are assumed to be reliable and effective, compared to other approaches. Lastly, the approach takes preference due to the exceptional estimates power, being found reliable and more efficient in small samples compared to that of the Johansen technique.

The technique requires the estimation of an error correction model of the form:

$\triangle F I N D E V_{t}=a+\sum_{i=1}^{p} a_{1} F I N D E V_{t-1}+\sum_{i=1}^{p} \vartheta_{i} S C R_{t}+\theta_{3} X_{t}+\vartheta_{2} t+u_{t} \ldots \ldots \ldots \ldots \ldots \ldots \ldots . .2$ The model 2 show how the lagged dependent variable, explanatory variables and their lagged components affect financial sector development in a single model.

After established cointegration, the Error Correction Model (ECM) was carried out so as to analyse what happens in the short run. The ECM model will describe all the dynamics of disequilibrium of variables in the short run. The ARDL model can also be used to drive the ECM by using a simple linear transformation that integrates long run equilibrium and short run adjustments without losing long run information.

\section{Granger Causality}

The Granger causality test was also used in the study to investigate the causality among variables of interest. The CGFS (2011) indicated that there can be a two-way relationship between financial sector development, especially the banking variable and sovereign credit 
ratings. Thus, issues in the banking sector may result in sovereign rating movements (Takawira and Mwamba, 2021). At the same time sovereign ratings may affect the banking sector. This therefore suggests that the two variables affect each other. The Granger causality test model was therefore utilized to analyse this type of relationship.

The Granger causality test model was therefore utilized to analyse this type of relationship. The model suggests that one variable maybe in a position to predict another variable. The idea of the test is to test if variable $\mathrm{X}$ causes $\mathrm{Y}$ or if variable $\mathrm{Y}$ causes $\mathrm{X}$ (Engle and Granger, 1987).

The Granger causality hypothesis that there is causality between two variables and, if the probability figure is less than $5 \%$, a null hypothesis will be rejected in favour alternative hypothesis and that will mean that there is a bidirectional relationship between the two variables, which means variable $\mathrm{X}$ causes $\mathrm{Y}$ and $\mathrm{Y}$ causes $\mathrm{X}$ in return.

Diagnostic tests were carried out on the results obtained. The diagnostic tests entail testing if the model is fit to be used for analysis (goodness of fit), particularly by analysing misspecification, serial correlation, and heteroscedasticity linked to the specified model (Brooks, 2008). To test for normality, the study adopted the Jarque-Bera test.

Several diagnostic tests were also carried out to examine the adequacy of the model. These tests include normality, homoscedasticity, autocorrelation and stability tests.

\section{Presentation of Empirical Results}

The chapter presents results of the models, which were estimated in previous section. The study seeks to examine the effect of sovereign ratings on financial development. In this regard, financial development is measured by DCP.

\section{Lag Length Selection (Financial Sector Model)}

Choosing the appropriate lag length is of importance in any regression. Asteriou and Hull (2011) shows that this is of importance to obtain Gaussian error terms. In other words, this will ensure that the model is adequate. Asteriou and Hull (2011:383) also show that this aspect to regression analysis is important as "setting the value of the lag length is affected by the omission of variables that might affect only the short-run behaviour of the model. This is because omitted variables instantly become part of the error term". The lag length employed was determined through the Akaike information criteria. As per Figure I, top 20 models are presented. The best model chosen is ARDL $(2,1,0,2,1,0)$. The ARDL model was therefore estimated based on this lag length.

Figure I:

Lag length Selection 
Akaike Information Criteria (top 20 models)

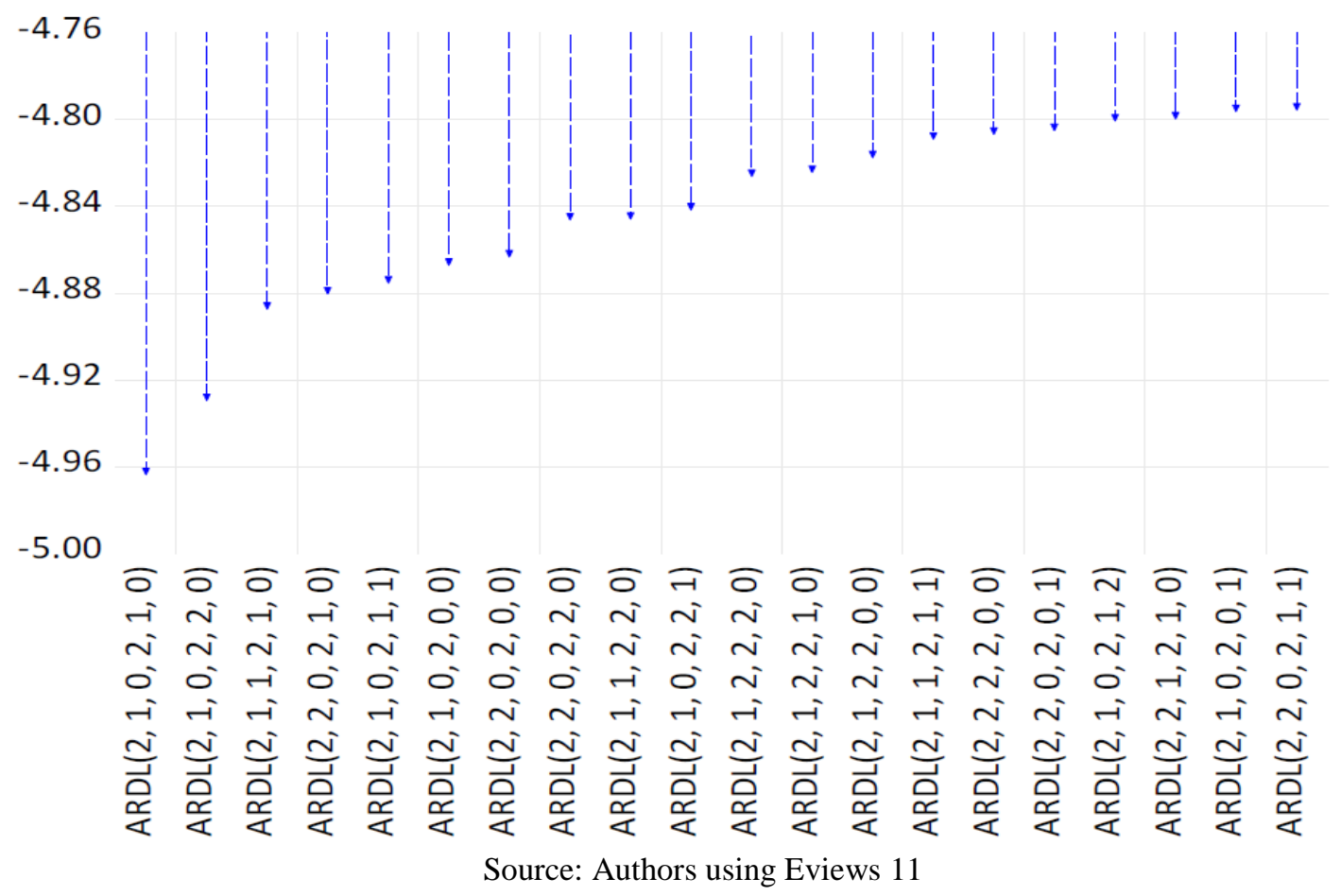

\section{Co-integration Results}

Having determined the lag length, bounds test for cointegration was estimated. The results are presented in table II. The results show that the calculated F statistic is 28.84 . This statistic is greater than the upper bound. This suggests a long-term association between the independent variables and dependent variables. This shows that all the variables estimated in the model in the long run move together.

Thus, financial sector development as measured by domestic credit to the private sector, foreign direct investment, gross domestic product, gross fixed capital formation, repo rate, cpi and sovereign rating all move together over time. Any change to these variables will significantly influence financial sector development in South Africa. This becomes important considering the role the financial sector plays generating development finance in the domestic economy. So, in other words, the findings in this section shows that financial conditions and sovereign ratings have a long-term relationship.

Table II:

ARDL Long-run Bounds Tests Results

\begin{tabular}{|c|c|c|c|c|}
\hline \multirow{2}{*}{$\begin{array}{l}\text { F-Bounds Test } \\
\text { Test Statistic }\end{array}$} & \multirow[b]{2}{*}{ Value } & \multicolumn{3}{|c|}{ Null Hypothesis: No Levels relationship } \\
\hline & & Significance & $\begin{array}{l}\text { Integrated at Order } \\
\text { Zero I(0) }\end{array}$ & $\begin{array}{l}\text { Integrated at } \\
\text { Order One I(1) }\end{array}$ \\
\hline & & \multicolumn{3}{|c|}{ Asymptotic: $\mathbf{n}=\mathbf{1 0 0 0}$} \\
\hline F-statistic & 28.84885 & $10 \%$ & 2.08 & 3 \\
\hline \multirow[t]{3}{*}{$\mathrm{K}$} & 5 & $5 \%$ & 2.39 & 3.38 \\
\hline & & $2.5 \%$ & 2.7 & 3.73 \\
\hline & & $1 \%$ & 3.06 & 3.73 \\
\hline \multirow[t]{8}{*}{ Actual Sample Size } & 22 & & Finite Sample: $n=35$ & \\
\hline & & $10 \%$ & 2.331 & 3.417 \\
\hline & & $5 \%$ & 2.804 & 4.013 \\
\hline & & $1 \%$ & 3.9 & 5.419 \\
\hline & & \multicolumn{3}{|c|}{ Finite Sample: $\mathbf{n}=\mathbf{3 0}$} \\
\hline & & $10 \%$ & 2.407 & 3.517 \\
\hline & & $5 \%$ & 2.91 & 4.193 \\
\hline & & $1 \%$ & 4.134 & 5.761 \\
\hline
\end{tabular}

$* * *=0.01$ level of significance 


$$
\begin{gathered}
* *=0.05 \text { level of significance } \\
*=0.1 \text { level of significance } \\
\text { Source: Authors using Eviews } 11
\end{gathered}
$$

\section{Long run Model -Financial Development regression}

Having established cointegration, the long run and short-run models were further estimated. These results are presented in Table III and IV.

Table III:

\begin{tabular}{|c|c|c|c|c|}
\hline Variable & Coefficient & Std. Error & t-Statistic & Prob. \\
\hline SCR & $0.2271 * * *$ & 0.104546 & 2.1732 & 0.0056 \\
\hline LFDI & $0.1333 * *$ & 0.006233 & 21.395 & 0.0297 \\
\hline LGDP & $2.9392 * *$ & 0.119289 & 24.639 & 0.0258 \\
\hline LGFCF & $0.2739 * * *$ & 0.048612 & 5.6350 & 0.0018 \\
\hline REPO & $-0.0259 * *$ & 0.001214 & -21.416 & 0.0297 \\
\hline CPI & $-0.0283 * *$ & 0.001524 & -18.575 & 0.0342 \\
\hline C & $-34.64799 * *$ & 1.098359 & -31.545 & 0.0202 \\
\hline
\end{tabular}

Long-run Model

Dependent variable: Financial sector Development

The empirical results as presented in Table III shows that the coefficient for sovereign rating is positive and statistically significant at $1 \%$ level. This result is consistent with the apriori expectation and theory in which a higher rating is expected to result in financial sector development improving. This is supported by Kim and Wu (2008), CGFS (2011) and Luitel and Vanpee (2018). These authors show that having a higher credit rating plays a huge role in reducing financial fragility.

Boot et al. (2005) shows that this is achieved in two ways. Firstly, the ability of the rating agencies to keep an eye on the ability of the country's credibility lower monitoring costs. Secondly, this plays a critical role in the decisions regarding the investment allocation of institutional investors such as pension fund managers who are restricted by regulatory constraints. Kim and $\mathrm{Wu}$ (2011) also show that in the event that a country is rated positively domestic banks may also access capital from the foreign interbank market at a lower cost. This also is in line with Luitel and Vanpee (2018) who highlight that funding costs for banks are related to sovereign ratings. The results thus suggest that sovereign ratings do have an effect on financial conditions in the country.

The empirical results also revealed that FDI, GFCF and GDP have positive coefficients and are highly significant. These results are in line with theory as well as apriori expectations. This result is also in line with the demand null hypothesis of Robinson (1952) in which demand of economic activities is what drives the growth of the financial sector. This result is also consistent with Odhiambo (2004), Thangagavelu and Jim (2004), Hondyian and Lolos (2005) and Shahnoushi et al. (2008). These authors argue that growth of the economy, which might manifest through increase in investment activities, is what drives the demand for 
financial services. Therefore, financial development is positively influenced by growth related activities.

The results also show that the relationship between inflation as measured by cpi and financial sector development in South Africa is negative. This agrees with the apriori expectation. These results were also found to be consistent with Boyd et al. (2001), Khan et al. (2006) and Gruyter (2017). These authors argue that lower levels of inflation are preferable. When inflation is high it has an effect on savings. Economic agents would prefer to purchase real assets instead of keeping cash. This will result therefore in a reduction in funds available to be allocated to generative areas of the economy. Thus, this impedes on the efficiency of the financial system. Khan et al. (2006) also shows that high levels of inflation may impede the flow of information, resulting in credit rationing to the private sector. This may exacerbate gaps in credit markets.

The empirical results also reveal that the interest rate has a negative effect on financial sector development. The coefficient is negative and statistically significant. These results are consistent with the apriori expectation. Even though there is limited literature that examines this phenomenon, higher interest rates may mean higher returns on investment, however this depends on the culture of saving in a country. South African savings are very low, indicating that higher interest rates may not translate to higher deposits. This may therefore be hard on the financial system as people struggle to service their debt. This may have an effect on financial stability.

\section{Error Correction Model - Financial Sector Development Regression}

The Error Correction model analysing the short-term relationship between all the variables of interest is presented on table IV.

Table IV:

Error Correction Model

Dependent Variable: Financial Sector Development

\begin{tabular}{lllll}
\hline Variable & Coefficient & Std. Error & t-Statistic & Prob. \\
\hline D(LDCP(-1) & 0.032040 & 0.006522 & 4.912759 & 0.1278 \\
D(SCR) & 0.113749 & 0.002356 & 48.29019 & 0.0132 \\
D(LFDI) & 0.054256 & 0.001453 & 37.35055 & 0.0170 \\
D(LGDP) & 2.612949 & 0.020064 & 130.2292 & 0.0049 \\
D(LGFCF) & 0.069511 & 0.009606 & 7.236489 & 0.0874 \\
D(REPO) & 0.009899 & 0.000124 & 79.54099 & 0.0080 \\
D(CPI) & -0.028033 & 0.000176 & -158.9458 & 0.0040 \\
D(CPI(-1)) & -0.007081 & 0.000121 & -58.53906 & 0.0109 \\
CointEq(-1)* & -0.535259 & 0.112117 & 4.7743 & 0.0050 \\
\hline R-squared & 0.999939 & Mean dependent var & 0.108822 \\
Adjusted R-squared & 0.999840 & S.D. dependent var & 0.057087 \\
S.E. of regression & 0.000721 & Akaike info criterion & -11.36992 \\
\hline \multicolumn{5}{c}{$* * * 01$ level of significance } \\
\\
\multicolumn{5}{c}{$* 0.05$ level of significance } \\
\end{tabular}

The short-run relationships between financial sector development and other independent variables is consistent with the long-run results as shown in the presented earlier. Also of importance is the ECM term which is negative (-0.5352) and significant at $1 \%$ level showing 
that if the variables move apart in the short run, they will move back together over time. This suggest that about $54 \%$ of the disequilibrium is corrected within a year. The next section presents the financial flows model results.

\section{Causality Test Results}

Table V. presents the granger causality tests results.

Table V:

Granger Causality tests Results

Dependent variable: $\mathrm{D}(\mathrm{LDCP})$

\begin{tabular}{llll}
\hline Excluded & Chi-sq & df & Prob. \\
\hline D(SCR) & 7.512376 & 2 & 0.0234 \\
All & 7.512376 & 2 & 0.0234 \\
\hline Dependent variable: D(SCR) & & & \\
\hline Excluded & Chi-sq & df & Prob. \\
\hline D(LDCP) & 1.319797 & 2 & 0.5169 \\
All & 1.319797 & 2 & 0.5169 \\
\hline & $* * *=0.01$ level of significance & \\
& $* *=0.05$ level of significance & \\
& $*=0.1$ level of significance & \\
& Source: Authors using Eviews 11
\end{tabular}

The results in Table $\mathrm{V}$ shows that the null hypothesis of no causal relationship could not be rejected from SCR to financial sector development at 5\% level of significance. This result suggests that whenever a country's sovereign rating is downgraded; this has a significant effect on financial sector development of a country. This result is consistent with the prior findings as well as the CGFS (2011) findings. However, there is no evidence of a unidirectional causality from financial sector development to sovereign rating.

\section{Diagnostic Tests for Financial development regression}

Several diagnostic tests were ran to check the adequacy of the models estimated. The results are reported on Table VI.

Table VI:

Diagnostic Tests

\begin{tabular}{|c|c|c|c|c|}
\hline Test & $\mathrm{H}_{0}$ & Test Statistic & p-value & Conclusion \\
\hline Jarque-Bera & $\begin{array}{l}\text { Residuals } \\
\text { normally } \\
\text { distributed }\end{array}$ & $\mathrm{JB}=2.7555$ & 0.2521 & $\begin{array}{ll}\text { Residuals are } \\
\text { normally } \\
\text { distributed }\end{array}$ \\
\hline Breusch-Godfrey & $\begin{array}{l}\text { No autocorrelation } \\
\text { in the residuals }\end{array}$ & $\mathrm{nR}^{2}(2)=4.714047$ & 0.8434 & $\begin{array}{l}\text { No autocorrelation } \\
\text { in the residuals }\end{array}$ \\
\hline $\begin{array}{l}\text { Breusch-Pagan- } \\
\text { Godfrey }\end{array}$ & $\begin{array}{l}\text { Residuals } \\
\text { homoscedastic }\end{array}$ & $\mathrm{nR}^{2}(2)=14.36930$ & 0.3484 & $\begin{array}{l}\text { Residuals are } \\
\text { homoscedastic }\end{array}$ \\
\hline
\end{tabular}

The results of diagnostic tests shows that the residuals are normally distributed, homoscedastic and do not have the problem of autocorrelation. The same also applies to the financial flows model.

Stability tests were also performed. The results are reported on Figure II and III. The results indicate that both the CUSUM and CUSUM Squares are stable. This therefore confirms that the model estimated is correctly specified. 
Figure II:

Stability Tests for the Financial Development Model

10.0

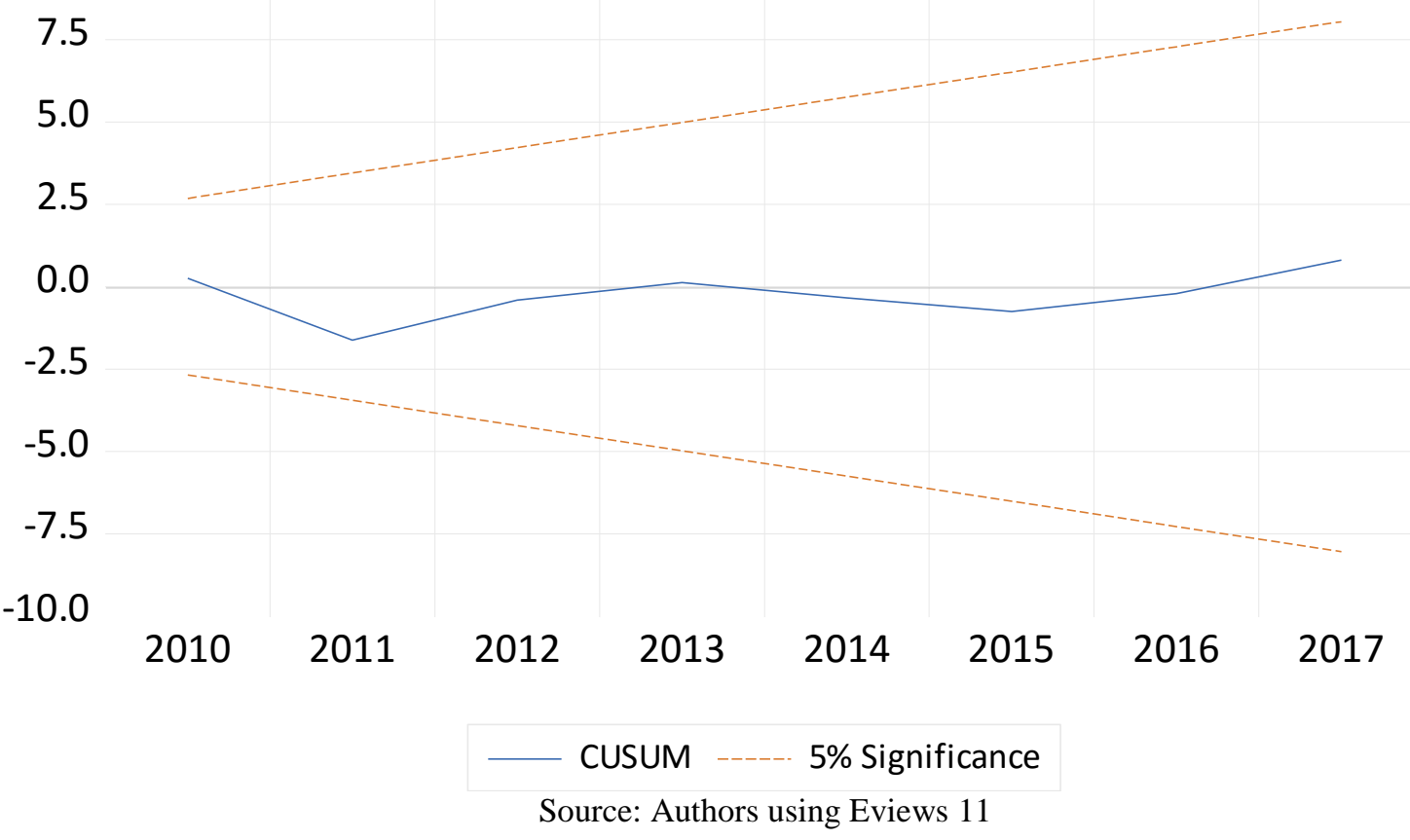

Figure III:

CUSUM of Squares Stability tests for the financial development model

1.6

1.2

0.8

0.4
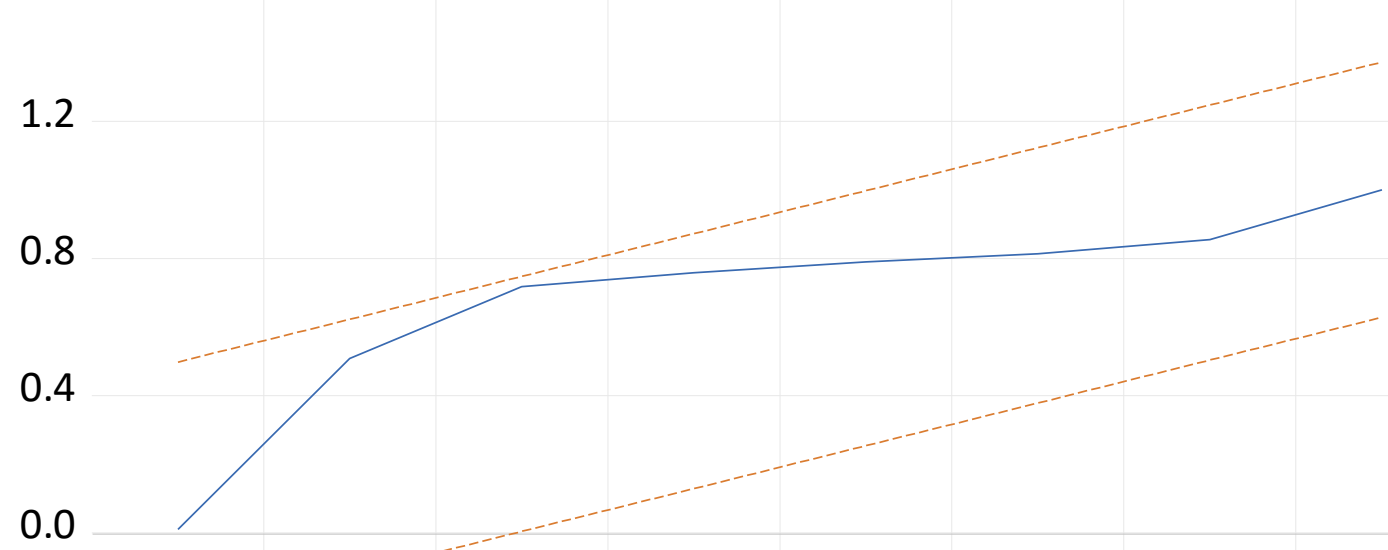

$-0.4$

$\begin{array}{llllllll}2010 & 2011 & 2012 & 2013 & 2014 & 2015 & 2016 & 2017\end{array}$

\section{_ CUSUM of Squares - ----. 5\% Significance}

Source: Authors using Eviews 11

The data was found to be integrated of order 1 and I (0). The Bounds tests were estimated for both the financial sector development variable. The results showed that there is evidence of cointegration. The long run as well as short-run models for both regressions were estimated. The results demonstrated that sovereign ratings have a positive effect on financial sector development as well as financial flows in South Africa. The ECM Models were estimated to 
check the short-run relationships. The results demonstrated if there is disequilibrium, the variables will again cointegrate after some time.

\section{Conclusion}

Based on the estimated models, a positive relationship exists in South Africa between financial development and the sovereign credit ratings. In other words, all the various financial development indicators employed were found to be significantly affected by sovereign ratings. This therefore suggest that higher ratings are associated with welldeveloped financial systems.

This result was found to be consistent with Boot et al. (2005), Kim and Wu (2008), CGFS (2011), Luitel, and Vanpee (2018). These authors show that having a higher credit rating plays a huge role in reducing financial fragility. This will therefore ensure financial stability and hence improve the financial sector development within the country. The literature on the subject also demonstrated that a positive sovereign rating affects domestic banks.

Another important observation from the analysis is the evidence of the supply-leading hypothesis looking at investment and GDP. These showed that they determine the growth of the financial system also. Thus, demand for financial resources was found to influence the expansion of the financial sector.

The positive relation between financial sector development and sovereign ratings suggests that countries which receives higher ratings are likely to have stable financial systems which can play the role of mobilising and allocating capital to the productive industries of the economy efficiently.

Thus, authorities should pursue policies which ensures that the country has stable macroeconomic variables as well as from the political sphere to ensure that the country receives a positive rating. Governments should focus on raising sovereign ratings and avoiding downgrades to boost financial development. There may be a need to deal with the issues which were raised by the rating agencies so as to ensure that in future the country is rated positively.

\section{References}

Abedian, I. (2016). Avoiding SA's Junk-Grade Sovereign Credit Rating. The Journal of the helen Suzman Foundation,78.

Adenutsi, D.E. (2010). Financial development, bank savings mobilisation and economic performance in Ghana: Evidence from a multivariate structural VAR. International Journal of Development Research and Quantitative Techniques 2(1), 3-24.

Alessandri, P. \& Haldane, A.G. (2009). "Banking on the State", Bank of England, mimeo, November, mimeo.

Ang, J.B. (2008). Household saving behaviour in an extended life cycle model: A comparative study of China and India. Journal of Development Studies 45(8), 13441359.

Asteriou, D. \& Hall, SG, 2011. Applied econometrics: A modern approach using EViews and microfit. Revised edition. Palgrave Macmillan, London.

Bayar, Y. and Kılıç, C. (2014). Effects of Sovereign Credit Ratings on Foreign Direct Investment Inflows: Evidence from Turkey. Journal of Applied Finance \& Banking, 4(2), 91-109.

Beck, T., Demirguc-Kunt, A. \& Levine, R.. (2000) A new database on financial development and structure, Policy Research Paper No. 2147, World Bank.

Berglund, A. \& Fransson, C. (2012). Sovereign credit rating effects on equity markets: Applied on US Data. 
Boot, A. W. A., Milbourn, T. T. \& Schmeits, A. (2005), Credit ratings as coordination mechanisms, Review of Financial Studies, 19(1), 81-118.

Boyd, J. H., Levine, R., \& Smith, B. D. (2001). The impact of inflation on financial sector performance, Journal of monetary Economics, 47(2), 221-248.

Brooks, C. (2008). Introductory econometrics for Finance. 2nd Edition. New York: Cambridge University Press.

CANUTO, O., DOS SANTOS, PABLO F. PEREIRA, \& DE SÁ PORTO, PAULO C (2012). Macroeconomics and sovereign risk ratings. Journal of International Commerce, Economics and Policy, 3(2), pp.1-25.

Carlin, W. \& Mayer, C. (2003). Finance, investment and growth, Journal of Financial Economics, 69, 191-226.

Charlin, V. \& Cifuentes, A. (2017). Reliability and agreement of credit ratings in the Mexican fixed-income market. The Journal of Credit Risk, 13(3), 21-45.

Chinn, M.D. \& Ito, H. (2006). What matters for financial development? Capital controls, institutions, and interactions. Journal of Development Economics, 81(1), 163-192.

Claessens, S. \& Laeven, L. (2003). Financial development, property rights and growth. Journal of Finance 58, 2401-2436.

Committee on the Global Financial System (2011). The impact of sovereign credit risk on bank funding conditions, Bank for International Settlements, CGFS Papers No 43.

Cooke, C. \& Bailey, F. (2015). The Impact of Credit Rating Changes on Jamaica's Global Bond Prices. Working Paper". Research and Economic Programming DivisionBank of Jamaica.

De Haan, J., \& Sturm, J. (2017). Finance and income inequality: A review and new evidence. European Journal of Political Economy, 50, 171-195.

Engle, R. \& Granger, C. (1987). Co-integration and Error Correction: Representation, Estimation, and Testing, Econometrica, 55(2), 251-76.

Falzon, J. (2013). Bank performance, risk and securitisation. GB: Palgrave Macmillan.

Fernandez, J. L. \& Vila, R. S. (2015). The credit agencies, institutional strengths and methodological weakness: The banks' ratings case.

Fisman, R. \& Love, L. (2004). Financial development and intersectoral allocation: a new approach. Journal of Finance 59, 785-2807.

Gande, A. \& Parsley, D.C. (2005). News spillovers in the sovereign debt market. Journal of Financial Economics 75, 691-734.

Greenwood, J. \& Jovanovic, B. (1990). Financial development, growth, and the distribution of income. Journal of Political Economy 98, 1076-1107.

Gropp, R.C., Gruendl, A \& Guettler, A. (2010). The impact of public guarantees on bank risk taking: evidence from a natural experiment, ECB Working Papers, no 1272.

Gruyter, DE (2017) The Effect Of Inflation On Financial Development Indicators In Iran (2000-2015), Studies in Business and Economics, 12(2).

Hondyian and lolos. (2005). Financial markets and economic growth in Greece, 1986-1999. International Financial markets, Institutions and Money, 15, 173-188.

Kapingura, F.M \& Alagidede, P. (2016). The relationship between financial sector development and savings mobilisation in South Africa: An empirical study, Development Southern Africa.

Khan, M. S., Senhadji, A. S., \& Smith, B. D. (2006). Inflation and financial depth, Macroeconomic Dynamics, 10(02), 165-182.

Khim-Sen Liew, V. (2004). On Autoregressive Order Selection Criteria, Computational Economics, University Library of Munich, Germany.

Kim, S.J. \& Wu, E. (2011). International bank flows to emerging markets: Influence of sovereign credit ratings and their regional spillover effects. Journal of Financial Research, 34(2), 331-364. 
Kim, S \& Wu, E. (2008). Sovereign credit ratings, capital flows and financial sector development in Emerging markets. University of New South Wales. Australia. NSW 2052.

Levine, R., (1997). Financial development and growth: views and agenda. Journal of Economic Literature, 35, 688-726.

Levine, R. \& Zervos, S. (1998). Stock markets, banks and economic growth. American Economic Review 88, 537-558.

Luitel, P. \& Vanpée, R. (2018). How do sovereign credit ratings help to financially develop low-developed countries?, ECMI Papers 13956, Centre for European Policy Studies.

Mutize, M. \& Mugobo,V.V. (2018). The Nexus Between Johannesburg Stock Exchange and the United States Unemployment Rate Announcement: An Impulse Response Analysis, Journal of Economics and Behavioral Studies, AMH International, 10(3), 160-168.

Nair, L.R. (2006). Financial sector liberalization and household savings in India. Indian Institute of Capital Markets 9th Capital Markets Conference Paper.

Ndikumana, L. (2005). Financial development, financial structure, and domestic investment: international evidence. Journal of International Money and Finance 24, 651-673.

Ntsalaze, Z, Boako, G. \& Alagidede, P. (2017). The impact of sovereign credit ratings on corporate credit ratings in South Africa, African Journal of Economic and Management Studies, 8, issue 2, 126-146.

Ntswane, L. (2014). The Impact of Sovereign Credit Ratings on Capital Flows and Financial Markets in Africa. PHD Thesis. Faculty of Commerce, Law and Management, University of the Witwatersrand, Johannesburg, South Africa.

Odhiambo, N.M. (2004). Is Financial Development still a Spur to Economic Growth? A Causal Evidence from South Africa. Savings and Development. 28(1), 47-62.

Panetta, F, T., Faeh, G., Grande, C., Ho., King, M., Levy, A., Signoretti, F., Taboga, M. \& Zaghini, A. (2009). An assessment of financial sector rescue programmes, BIS Papers, 48 .

Pesaran, M. H \& Pesaran, B. (1997). Working with Microfit 4.0: Interactive Econometric Analysis, Oxford University Press, Oxford.

Rajan, R.G. \& Zingales, L. (1998). Financial dependence and growth. American Economic Review 88, 559-586.

Robinson, J. (1952). The Rate of Interest and Other Essays. Macmillan, London.

Rosenius, S. \& Sharafuddin, N. (2013). The Effects of Moody's Sovereign Ratings on European Stock Markets.

Sahoo, P. \& Dash, R.K. (2013). Financial sector development and domestic savings in South Asia. Economic Modelling 33, 388-397.

Shahnoushi. N, et. Al. (2008). Causality Between Financial Development and Economic Growth in Iran. World Applied Science Journal. 4(5), 736-740.

Stulz, R., Williamson, R., (2003). Culture, openness and finance. Journal of Financial Economics 70, 313-349.

Suk-Joong, K. \& Wu, E. (2007). Sovereign credit ratings, capital flows and financial sector development in emerging markets, Emerging Markets Review,9(1), 17-39.

Takawira, O. and Mwamba, W.M.,2020. Determinants of Sovereign Credit Ratings: An Application of the Naïve Bayes Classifier. Eurasian Journal of Economics and Finance, 8(4), pp.279-299. DOI: 10.15604/ejef.2020.08.04.008

Takawira, O. and Mwamba, W.M., (2021). The effects of sovereign ratings on financial stability in South Africa. African Journal of Business \& Economic Research., Vol. 16 Issue 1, p27-65. DOI: https://doi.org/10.31920/1750-4562/2021/v16n1a2

Thangagavelu, S. \& Jium K. (2004). Financial Development and Economic Growth in Australia: An Empirical Analysis. Empirical Economics. 29(2), 247-260. 
Venkatraman, P. (2015). The share price reaction to credit rating announcements on the Johannesburg Securities Exchange, Gordon Institute of Business Sciences, University of Pretoria, Unpublished dissertation.

Wortmann, K. (2010). Assessing the determinants of foreign portfolio investment to emerging market: The case of South Africa (1994- 2010), University of Cape Town. 